\title{
Urban Floods and Residential Rental Values Nexus in Kumasi, Ghana
}

\author{
Elvis Attakora-Amaniampong \\ Department of Real Estate and Land Management, University for Development Studies WA, Ghana
}

\section{Ebenezer Owusu-Sekyere ${ }^{23}$}

Department of Development Studies, University for Development Studies WA, Ghana

oseturbo@yahoo.com

and

\begin{abstract}
Dacosta Aboagye
Department of Geography and Rural Development, Kwame Nkrumah

University of Science and Technology, Kumasi, Ghana

DOI//http://dx.doi.org/10.4314/gjds.v13i2.10
\end{abstract}

\begin{abstract}
The supposition that the occurrence of flood event will have an inverse effect on rental values of residential housing properties is often accepted as a fact. However, the mechanism for this supposed impact has not been clearly articulated and the hypothesis is far from proven in Ghanaian housing rental market. This paper examined the impact of flood on residential rental values in Kumasi. The study adopted multiple research approaches in selecting zones with both flood and non-flood liable residential properties. The repeated sales model was then used to create local market indices to gauge flood impact on the rental values. The rental values of non-flooded residential properties were generally higher than their flooded counterparts by a margin of GHS $62.66 \pm 0.09$ annually. While this supports existing postulations of a negative impact of flood on rental values, the results further showed that the extent of the impact varies across different residential property types. It is concluded that the wholesale assumption in literature that flood events diminish rental values should be interpreted with caution. The study recommends that the (dis)amenity effects of flood on rental values should therefore be assessed on case by case basis.
\end{abstract}

Keywords: Floods, Ghana, Kumasi, Residential Rental Value, T-test

23. Corresponding author: Ebenezer Owusu-Sekyere 


\section{Introduction}

Disasters, especially those that seem principally to be caused by natural hazards such as flood events are the greatest threat to humanity (Wisner et al., 2004). The lethal reputation of flooding events destroys development gains at greater proportions and shortens the lives of many of the world's population (UNISDR, 2011).The Office for the Coordination of Humanitarian Affairs of the United Nations (OCHA) for example, reports that in 2012, more than one and a half million people were affected by floods in Niger, Chad, Senegal and Nigeria and that more than 129400 homes were destroyed (OCHA, 2012). Available literature (Aboagye, 2012; Larsen, 2012; Munich Reinsurance Company, 2013) estimates that the average annual economic losses associated with flooding are in excess of 40 billion USD per year. The increasing cost of flood disasters in the past decennium has re-ignited a significant research on the hazards of flood and its impact on humans and their valuable assets (Aboagye, 2012; Larsen, 2012; Efstratiadis et al., 2013). The consequences of urban floods from available scholarly works particularly highlight the increasing evidence of negativity on houses and their values in terms of sales (Leggett and Bockstael, 2000; Kim et al., 2003; Mansfield et al., 2005; Gibbons et al., 2008; Gibbons \& Machin, 2008), with only a handful of the studies empirically estimating the impact of urban flooding on residential rental values (Orford, 2002; Eves, 2004).

In Ghana, there is large academic and policy inventory on impact of flood events on society (Karley, 2009; Oppong, 2011; NADMO, 2014), but literature search on the relationship between flood events and residential rental values did not return any empirical study as is the case in the developed 'north' as previously explained. The researchers agree that flood events in Ghana have taken hundreds of lives and destroyed properties worth millions of USD. But to focus on these (in the understandably humanitarian way that outsiders do in response to such tragedies) is also to ignore the effects of flood events on other economic indicators including residential rental values. This situation creates knowledge gap, a gap which must be filled with a research of this nature in the Ghanaian context where residential property types and the rental market may be radically different. This article interrogates the impact of flood events on rental values of the four common residential property types (single room; chamber and hall; two-bed room and three-bed room apartment types) in Kumasi, the second largest city of Ghana and one that has experienced more than ten devastating flood events between 2006 and 2014 (NADMO, 2014).

Understanding how residential rental values respond to flooding is an important question for many reasons. First, as observed by Pryce et al. (2011), spatial variation in the location of a unit of housing can in principle, reveal the money value of the welfare loss associated with vulnerability to flooding. It will also help estimate the total impact 
of floods on human wellbeing and serves as a basis for planning housing. This can enhance human settlement programmes and policies, evaluation and monitoring of housing conditions and societal needs assessment within the context of the national development. Lastly, understanding of the relationship between flood impact and rental value is essential to homeowners who rely on housing as their major source of income for retirement. The potential for floods to wipeout housing wealth accumulated over a person's lifetime is of particular concern in societies where there are high rates of homeownership and of households with undiversified portfolios (Cauleyet al., 2007). The paper is structured in five sections. After the introductory section, the second section discusses the contextualization of residential rental values and flood impact nexus. The third section describes the research approach. Section four presents the results and discussions of the study. The final section concludes and gives recommendations.

\section{Literature Review}

The rental value of a residential property is defined as the amount of money paid usually per annum by tenant to landlord for access and usage of the residential property (Aliyu et al., 2012; Larsen, 2012) and is influenced by certain factors such as location, age, structural characteristics and many others (Howley, 2009). The dynamics of rental values depend on the elasticity of both demand and supply of a particular rental space type (Geltner et al., 2006, Lamond et al., 2007; Larsen, 2010, 2012). The rental market is highly segmentedand tends to be local rather than national, and specialized around building usage categories (Geltner et al., 2006). Adegoke (2014) examined critical factors that influence residential property rental values in three urban areas in Nigeria based on hedonic pricing model, which is quantitative tool for gauging property values. The study revealed that different building types have different critical factors influencing their rental values within different residential densities (Adegoke, 2014). Blair and Larsen (2010) tested the effect of social relationship satisfaction on rental values of houses, based on a semi-logarithm regression model in Dayton, Ohio. It was revealed that resident satisfaction with their neighbours is a key determinant of residential rental values. This paper is of importance as it is among the first effort to introduce social capital in analyzing rental values by the hedonic model. This supports the works of Lukkarinen (2005); Choe \& Peterson (2009); Nilsson et al. (2006); Woolley et al. (2008) and Kleinhans (2009) on the importance of social relationships among residents.

Using a hedonic regression model, Selim (2008) studied factors influencing house prices in Turkey by analyzing 2004 Household Budget Survey Data in Turkey. To Selim, the type of house, type of building, number of rooms, size, and other structural characteristics such as water system, pool, natural gas were the major determinants of house rental values (Selim, 2008). Olujimi\& Bello (2009) evaluated the availability and effect of 
infrastructure on rental values in residential property in Nigeria, particularly in the Akure of the Ondo State. The study utilized the hedonic approach based on regression analysis. The results showed that, $30.5 \%$ of rental values of residential buildings were attributed to infrastructural facilities particularly the provision of wall-fence and windows with burglar proof. Subsequently, they recommended that for residential properties to command competitive rental values, amenities likewall-fence and windows with burglar proof amongothers should be provided (Olujimi \& Bello, 2009). Larsen (2010) reported on a study to determine whether investors pay less for single-family houses than do buyer/residents. This was done by subjecting transactional data from 3,443 single-family houses to regression analysis and it was confirmed that on average investors systematically pay 13.23 per cent less than those residing in the houses (Larsen, 2010). Other studies supported location as one of the key determinants of residential property rental value (for example, Olujimi \& Bello, 2009; Howley, 2009; Aliyu et al., 2012). In addition, locations do influence residential rental values through tangible or intangible mode as labelled by Aliyu et al. (2012).

Globally, research on the impact of flooding on residential property value have provided variant outcomes attributed partly to differing methodological approaches and partly to the nature and type of the impact or flood risk gauged. Broadly, three schools of thought about flood impact on property values are discernible. Proponents of the first school of thought hold the view that there is an inverse relationship between flood impact and property values. This school of thought contend that housing properties located in flood prone areas attract lower prices than those located farther away (Eves, 2002; Samwinga et al., 2004; Environment Agency/DEFRA, 2004; Wordsworth and Bithel, 2004; Lamond et al., 2005;Lamond et al., 2007; Larsen, 2012). They contend further that in most cases, property values are discounted after major flood events. Harrison et al. (2001) suggests that the occurrence of flood event is a key driving factor for the discount in house rents experienced by owners of property sited on flood plains. Divergently, the second school of thought concludes that there is no impact of flood events on property values (Bialaszewski \& Newsome, 1990). They argue that there have been many instances where zero impact of flood on property values is revealed (cited in Lamond et al., 2005; Lamond \& Proverb, 2006). The last school of thought proclaim that flooded property can achieve a premium over non-flooded equivalent (Montz, 1993). They contend that flood effects are positive and that in the long term flooded property can yield a premium over its nonflooded counterparts (Montz, 1993 as cited in Lamond et al., 2005).

Our research is under-pinned by the theoretical profiling of flood impact on property value propounded by Tobin \&Montz (1994). The framework is based on a combined literature from urban economics and flood hazard. The profile is also based on the premise that land value is determined by time, frequency and severity of flood. The 
theory among other things stipulate that socio-economic and environmental features including flooding conditions dictate the speed and scale of property value recovery into four simple profiles (Figure 1) (Lamond\&Proverb, 2006). Profile 1 in Figure 1 depicts a scenario of a one-off previously Flooded Property Value (FPV) with a temporal depression where later the FPV recovers. In this case the effect of inflation is ignored for clarity. This can be experienced at flood liable areas with a lower flood risk as risk of return is low after a flash flood which does not induce property value to remain low. In this scenario property value recovery time is most probably shorter than the reinstatement time. Again, this profile might prevail at a low flood risk region where residents collectively forget about flood risk over time as experienced in Sydney (Eves, 2004). This will have a longer recovery period than that of flash flood as indicated by Lamond \& Proverb (2006).

Profile 2 shows a scenario where a previously flooded property value increases relatively higher above the non-flooded property values as supported by Montz (1992) and Tobin \&Montz (1994). Though, it sounds far from reality, some of the explanations as indicated by Lamond\& Proverb (2006) were that post-flood reinstatement might lead to betterment of previously flash flooded properties and their values attributed to events such as the provision of flood defence, building standards higher than the original standards and updating fixtures and decoration. Profile 3 represents a situation where an occurrence of flood brings about new but permanent perception about an area being liable to flooding. This scenario can occur when residents of a high-risk area noted for persistent flooding tend to forget about flood events for a longer period of time. In this case, an unexpected flood incident might renew their awareness permanently. Lamond \& Proverb (2006) support this example with the 1998 and 2000 floods that occurred in the UK after about two decades of prolonged dry period. Profile 4 symbolises a scenario that if flooding is regular and has already been factored into house prices then the impact of one event of flood will be zero. Based on this, the zone and its residents will be enjoying policies such as mandatory insurance and cost rebate. In such instances, a new flood event will yield no impact on new home purchasers or tenants (Lamond \& Proverb, 2006). 


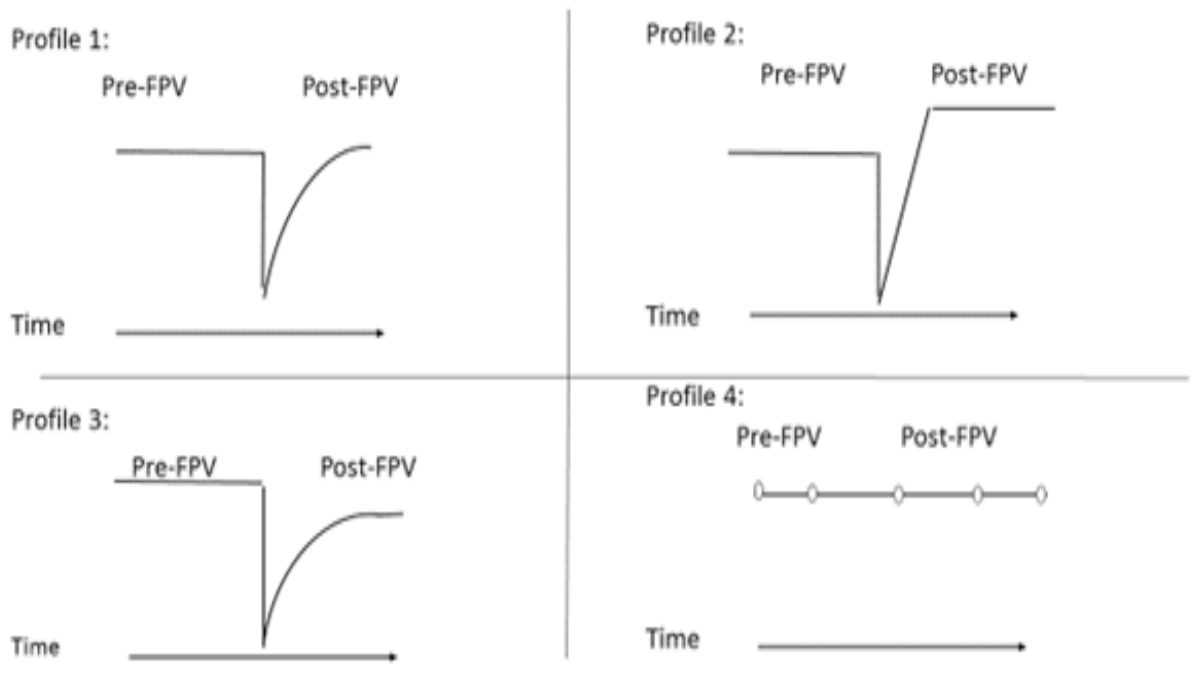

Fig 1: The four profiles-flood impact on property values

Source: Modified from Lamond\& Proverb (2006)

\section{Methodology}

\section{Study area}

The study was conducted in Kumasi which is situated in the transitional forest zone and located about $270 \mathrm{~km}$ north of the national capital, Accra (GSS, 2010). The unique centrality of the city as a traversing point from all parts of Ghana makes it a special place for many to migrate. The city is traversed by major rivers and streams which include the Subin, Wiwi, Sisai, Owabi, Aboabo, Nsuben among others (Danquah et al., 2011). However, anthropogenic activities in terms of estate development, encroachment and indiscriminate waste disposal practices have impacted negatively on the drainage system and have consequently brought these water bodies to the brink of extinction (Owusu-Sekyere et al., 2016).

The high rate of population growth coupled with the high migrant numbers has outstripped the rate of infrastructure development and service provision (GSS, 2010). Most of the facilities have exceeded their carrying capacities. Houses in the metropolis can be classified into about five types (KMA, 2014). These include: single storey traditional compound houses, multi-storey compound houses, government-built detached or semi-detached for low-income households, large single household houses built on relatively large plots and block of flats. The housing environment in some parts of Kumasi especially Oforikrom, MoshieZongo, Sawaba, Ayigya Zongo and Aboabo 
are unsightly and characterized by poor drainage and sanitation. The 2010 population census indicates Kumasi has 20.5 per cent of the regional housing stock (GSS, 2010). The KMA reports that the city keeps expanding with new housing infrastructure. Old houses in the city centre are currently being pulled down to make way for new and ultra-modern structures (KMA, 2014). It is therefore important for the authorities to determine the direction of growth.

The city's population is growing at a rate of 5.47 per cent per annum whilst housing supply is growing at 2.9 per cent per annum (KMA, 2014). Obviously population growth far outstrips housing production and therefore supply of housing is still below the required demand (GSS, 2010). The GSS further estimates that 1 per cent increase in population requires about 3 per cent increase in housing infrastructure.

\section{Data Set}

To accomplish the objectives of the study, two methodological approaches were adopted: the experimental block design which allows for the selection of multiple sites and the repeated sales model proposed by Lamond et al. (2007) which is used to track the impact of flooding through time. The former was used for the identification and selection of neighbourhoods of identical location attributes. The essence of experimental block design was to offset the consequence of variables attributed to differences in location. It also yields consistency in flood impact across different periods. After selecting the residential blocks for the study, the study then adopted the repeated sales model to gauge the floods impact on the rental values of the different property types. According to Lamond et al. (2007), all things being equal, in specifying the repeated sales model through the experimental block design to gauge the floods impact on property value, the price of property (i) at time period ( $t$ ) can be expressed in a logarithmic form as:

Where;

$$
\begin{aligned}
& \operatorname{InP} P_{i t}=\sum_{j=1}^{J} \beta_{j} \operatorname{InX} X_{j i t}-\gamma Z_{i t}+C_{t}+\varepsilon_{i t} \\
& \operatorname{InP}_{i t}=\text { the price of property }(\mathbf{i}) \\
& \beta_{j} \quad=\text { vector of coefficients representing the elasticity of price with respect to the } \\
& \text { matrix of location and property specific explanatory variables } \boldsymbol{X}_{j i t} \text {; } \\
& \boldsymbol{Z}_{i \boldsymbol{t}} \quad \text { = flood status variable at time } \mathbf{t} \text { with coefficient }-\boldsymbol{y} \text { (o if not previously flooded } 1 \text { if } \\
& \text { previously flooded); } \\
& \varepsilon_{i t} \quad=\text { error term } \\
& \boldsymbol{c}_{\boldsymbol{t}} \quad \text { = a generalised logarithmic market growth term }
\end{aligned}
$$


In adopting the proposed model, we substituted residential property prices with residential property rental values. Hence the modified equation for calculating the relation between flood-impact and residential property rental values can be written as:

$\operatorname{InR}_{i t}=\sum_{j=1}^{J} \beta_{j} \operatorname{In} X_{j i t}-\gamma Z_{i t}+C_{t}+\varepsilon_{i t}$

... Equation1

Where;

In $_{\boldsymbol{i t}}=$ the rental value of property $\mathrm{i}$

$\beta_{j}=\quad$ vector of coefficients representing the elasticity of rent with respect to the matrix of location and property specific explanatory variables $\boldsymbol{X}_{j i \boldsymbol{i}}$;

$\boldsymbol{Z}_{\boldsymbol{i t}}=$ flood status variable at time $\mathrm{t}$ with coefficient $\boldsymbol{- y}$ (o if not previously flooded $\mathbf{1}$ if previously flooded);

$\varepsilon_{i t}=\quad$ error term is distributed mean o and variance se 2; and

$\boldsymbol{c}_{\boldsymbol{t}}=$ a generalised logarithmic market growth term.

Based on the assumptions of the repeated sales model, a renewal of rent of the same property (i) at a subsequent period ( $\mathbf{t}+\mathbf{k})$ will change equation (1) to equation (2) as:

$$
\operatorname{In} R_{\mathrm{it}+\mathrm{k}}=\sum_{\mathrm{j}=1}^{\mathrm{J}} \beta_{\mathrm{j}} \operatorname{In} \mathrm{X}_{\mathrm{jit}+\mathrm{k}}-\gamma \mathrm{Z}_{\mathrm{it}+\mathrm{k}}+\mathrm{C}_{\mathrm{t}+\mathrm{k}}+\varepsilon_{\mathrm{it}+\mathrm{k}} \quad \text {..Equation2 }
$$

Hence, the change in rent of property (i) between period ( $\mathbf{t})$ and period $(\mathbf{t}+\mathbf{k})$ can be given as (equation 2) minus (equation 1). The characteristics of property (i) and of its location were held constant between the periods $(\mathbf{t})$ and $(\mathbf{t}+\mathbf{k})$. Again, the differences in characteristics of both flooded and non-flooded properties between period $t$ and $\mathrm{t}+\mathrm{k}$ were also held constant. This implies that the location and property specific characteristics of property (i) react to give zero, after which the growth effect of the change in flood status was derived. Here, the time period was limited to two-before and after flood event. Now the model becomes analogous to the "difference-in-difference" (D-in-D) model of Gibbons and Machin (2005) as indicated and adapted by Lamond et al. (2006). By using the non-flooded property rental values as a control sample and flooded property rental values as the treated samples, the changes in rental values (R) between the two periods, that is before flood (P1) and after floods (P2) for both flooded (f) and non-flooded (nf) properties were gauged. Hence, the differences between flooded rental values and non-flooded rental values were computed to assess the flood impact on rental values (table 1). The flood-impact significance was tested using t-test analysis. 
Table 1: Difference-in-difference model

\begin{tabular}{|c|c|c|c|}
\hline RentalValues & Before Flood (Pl) & AfterFlood (P2) & Difference \\
\hline Non-flooded Rental Values $\left(R_{n f}\right)$ & $\mathrm{R}_{\mathrm{nf1}}$ & $\mathrm{R}_{\mathrm{nf} 2}$ & $\mathrm{R}_{\mathrm{nf2}}-\mathrm{R}_{\mathrm{nf} 1}$ \\
\hline Flooded Rental Values $\left(R_{i}\right)$ & $\mathrm{R}_{\mathrm{f} 1}$ & $R_{f 2}$ & $R_{f 2}-R_{f 1}$ \\
\hline Difference-im-Difference & & & $\left(R_{n f 2}-R_{n f 1}\right)-\left(R_{f 2}-R_{f 1}\right)$ \\
\hline
\end{tabular}

The data set for this study were collected in a seven-month period (April-September, 2015). The period between April and September is when the impact of the rainy season and its resultant flooding event is greatly felt in Ghana. The data consisted of rental values of flooded residential properties and rental values of non-flooded residential properties from Dichemso, Aboabo and Atonsu (see figure 2).

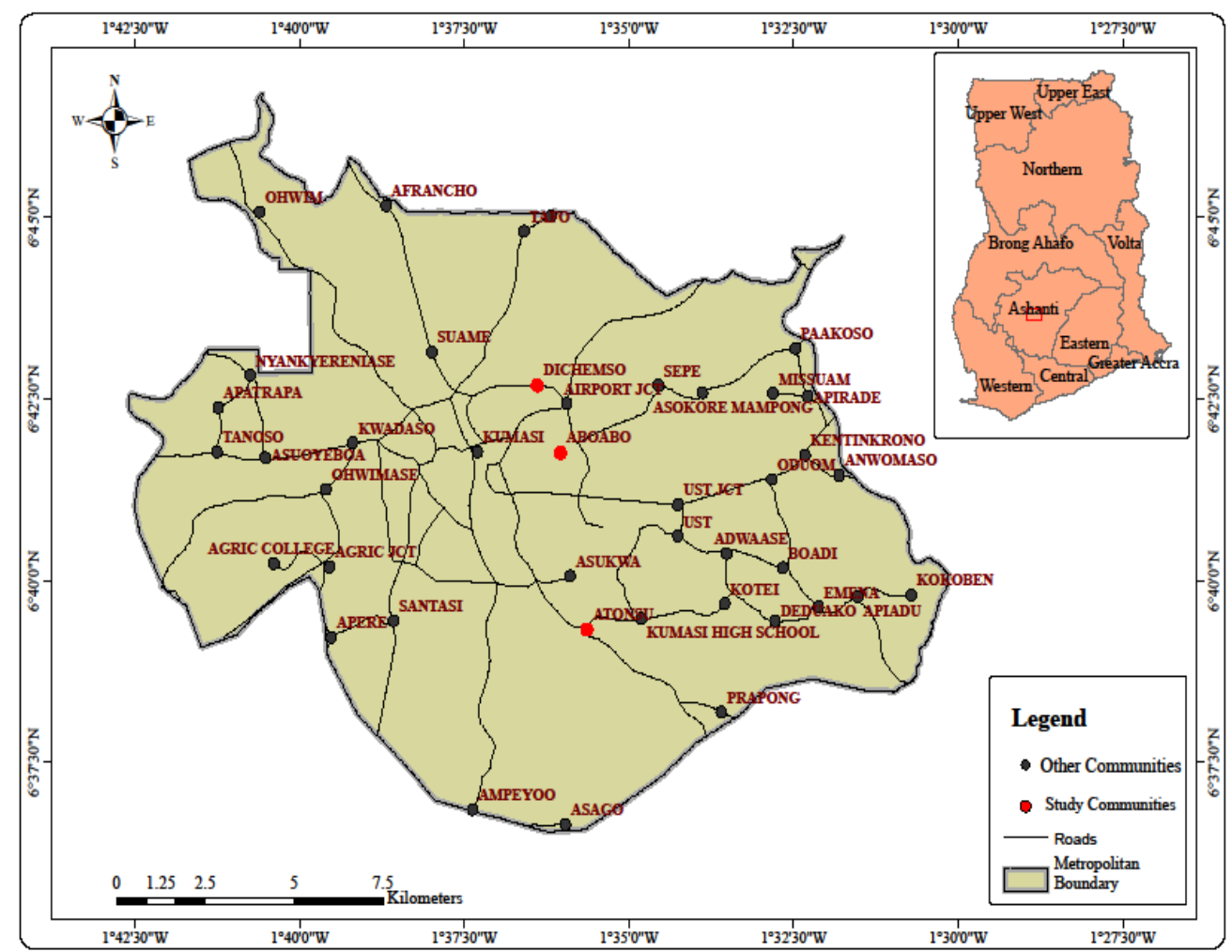

Fig 2: Map of Kumasi showing study communities

Source: Authors' Construct, March 2015.

These study sites were selected based on the fact that for the past five years preceding the study, they have experienced consistent flooding events of higher magnitudes with some of the events reaching the scale of national disasters (NADMO, 2014). For the purpose 
of this study, each community is referred to as "Block" because it has identical location attributes. Two categories of houses within each of the Blocks were chosen: residential properties that have not suffered flooding in the last five years preceding the study and residential properties that have continuously suffered annual flooding in the last five years preceding the study. The assumption was that tenants in those residential properties could speak to the economics of rental values and its relationship with the environmental (dis)amenity. The five-year base period was chosen because a GSS report on the housing rental market in Kumasi (GSS, 2010) indicate that tenants go through a rental payment circle of between two and five years (advance payment system) after which a re-negotiation is done depending on the tenant's satisfaction or otherwise with the use of the facility. Based on this understanding, first time residents were excluded from the study. In all, 36 flooded and 60 non-flooded residential properties were selected using rental value attributes such as location and other property specific determinants (see table 2).

Table 2: Selection of residential property types

\begin{tabular}{|l|l|l|l|l|}
\hline Non-flooded Properties & Dichemso & Aboabo & Atonsu & Total \\
\hline SRA & 10 & 15 & 12 & 37 \\
\hline CHA & 8 & 3 & 5 & 16 \\
\hline 2BA & 1 & 1 & 2 & 4 \\
\hline 3BA & 1 & 1 & 1 & 3 \\
\hline TOTAL & 20 & 20 & 20 & 60 \\
\hline Flooded Properties & Dichemso & Aboabo & Atonsu & Total \\
\hline SRA & 4 & 6 & 9 & 19 \\
\hline CHA & 3 & 2 & 4 & 9 \\
\hline 2BA & 2 & 2 & 1 & 5 \\
\hline 3BA & 2 & 0 & 1 & 3 \\
\hline TOTAL & 11 & 10 & 15 & 36 \\
\hline
\end{tabular}

SRA - Single-room Apartments, CHA - Chamber and Hall Apartments, $2 B A$ - Two-bedroom Apartments, $3 B A-$ Threebedroom Apartments

The data were collected from tenants occupying Single-room Apartments (SRA), Chamber and Hall Apartments (CHA), Two-bedroom Apartments (2BA) and Threebedroom Apartments (3BA). The survey covered tenants who had resided in their apartments for more than five years. A team of five researchers conducted and administered the questionnaire using the face-to-face approach. This approach was adopted because tenants' busy schedule and limited educational accomplishment did not make it possible for them to read and answer the questions by themselves. There were a lot of instances the researchers had to read the items, and also interpret in the 
local language (Twi) before the appropriate responses were obtained. The respondents' appreciation of the annual flooding event and how the situation influences their rent were further solicited by prompting historical accounts and positioning these conditions within the context of current daily experiences. The questionnaire explored issues including: how long they have stayed in the community, how much they pay monthly and yearly as rent, how they negotiate for the rent and environmental concerns in the community, viz-a-viz the annual flooding event. The responses were coded and analyzed quantitatively on monthly and annual basis.

The actual range of rental values for both flooded and non-flooded properties were small. The data were further analysed to determine the averages on yearly basis for flooded and non-flooded properties. These were t-tested to see whether non-flooded rental values were significantly higher than the flooded counterpart. This was done across all property types (Single-room Apartments, Chamber and Hall Apartments, Two-bedroom Apartments and Three-bedroom Apartments). To estimate the difference on average between the non-flooded rental values $\left(\boldsymbol{R}_{\boldsymbol{i t}}\right)$ and flooded rental values $\left(\boldsymbol{R}_{\boldsymbol{i t}+\boldsymbol{k}}\right)$ which was also done on yearly basis, a confidence interval estimator of $\left(\boldsymbol{R}_{\boldsymbol{i t}}-\boldsymbol{R}_{i t+k}\right)$ when variance of $\left(\boldsymbol{R}_{\boldsymbol{i t}}\right.$ and $\left.\boldsymbol{R}_{\boldsymbol{i t}+\boldsymbol{k}}\right)$ are unequal was used. At confident level of 95\%, this is mathematically represented as;

$$
\bar{R}_{i t}-\bar{R}_{i t+k} \pm t_{\alpha / 2} \sqrt{\left(\frac{1}{n_{t}}+\frac{1}{n_{t+k}}\right)}
$$

\section{Results and Discussion}

The results show that the mean rental values of flooded and non-flooded residential property types respectively were 19.16 and 67.30 for Single-Room Apartments; 77.22 and 143.75 for Chamber and Hall Apartments; 146.00 and 248.75 for Two-bedroom Apartments and 296.67 and 338.33 for Three-bedroom Apartments (see table 3 ) indicating that the rental values of non-flooded properties were higher than their flooded counterparts per annum. 
Table 3: Meanrental values of flooded and non-flooded residential property types

\begin{tabular}{|c|c|c|c|c|c|c|c|c|c|c|}
\hline \multirow{2}{*}{\begin{tabular}{|l|} 
Property \\
F status \\
\end{tabular}} & \multicolumn{2}{|l|}{ SRA } & \multicolumn{2}{|l|}{ CHA } & \multicolumn{2}{|l|}{$2 \mathrm{BA}$} & \multicolumn{2}{|l|}{$3 \mathrm{BA}$} & \multicolumn{2}{|c|}{ All Property Types } \\
\hline & $\mathrm{F}$ & NF & $\mathrm{F}$ & NF & $\mathrm{F}$ & NF & $\mathrm{F}$ & NF & $\mathrm{F}$ & NF \\
\hline Count & 19 & 37 & 9 & 16 & 4 & 5 & 3 & 3 & 39 & 60 \\
\hline MRV & 19.16 & 67.30 & 77.22 & 143.75 & 146.00 & 248.75 & 296.67 & 338.33 & 70.67 & 113.33 \\
\hline Variance & 1.14 & 13.05 & 13.19 & 45.00 & 30.00 & 6.25 & 633.33 & 658.33 & 5077.66 & 5419.04 \\
\hline Tail Test & One & Two & One & Two & One & Two & One & Two & One & Two \\
\hline Std error & 0.64 & 0.64 & 2,07 & 2,07 & 2,75 & 2,75 & 4,72 & 4,72 & 15,21 & 15,21 \\
\hline t-stat & 74.94 & 74.94 & 32.15 & 32.15 & $37 \cdot 36$ & $37 \cdot 36$ & 18.39 & 18.39 & 2.81 & 2.81 \\
\hline Df & 46.59 & 46.59 & 22007 & 22007 & 5,83 & 5,83 & 2.56 & 2.56 & 75.75 & 75.75 \\
\hline $\mathrm{P}$-value & $1.57 \mathrm{E}-50$ & $3.15 \mathrm{E}-50$ & $6.34 \mathrm{E}-21$ & $1.27 \mathrm{E}-20$ & $1.83 \mathrm{E}-\mathrm{o} 8$ & $3.65 \mathrm{E}-08$ & 0.000434 & 0.000868 & 0.0032 & 0.0064 \\
\hline $\mathrm{t}$-crit & 1.68 & 2.01 & 1.68 & 2.06 & 1.04 & 2.45 & 2.36 & 3.18 & 1.67 & 1.99 \\
\hline Lower & - & -49.43 & - & -70.81 & - & -109.48 & - & -101.67 & - & -73.96 \\
\hline Upper & - & -46.85 & - & -62.25 & - & -96.02 & - & -71.67 & - & -12.37 \\
\hline Sig & yes & yes & yes & yes & yes & yes & yes & yes & yes & yes \\
\hline Effect $r$ & 0.99 & 0.99 & 0.99 & 0.99 & 0.99 & 0.99 & 0.99 & 0.99 & 0.31 & 0.31 \\
\hline
\end{tabular}

F - Flooded property, NF - Non-flooded property, MRV-mean rent values

The equality of variance status of the two sets of data for all the property types were tested and confirmed to be unequal, using the "Real Statistics" data analysis tool. The unequal variances for all non-flooded and flooded properties rental values were further confirmed using the "PHStat 4" - another data analysis tool. The results indicated that using five different t-tests based on both one and two tail tests, all the non-flooded property types had higher rental values than their flooded counterparts. The results showed that the differences between the two rental values for all the t-tests were also statistically significant (Table 3).

In estimating the extent of differences on average, between the non-flooded rental values $\left(\boldsymbol{R}_{\boldsymbol{i}}\right)$ and flooded rental values $\left(\boldsymbol{R}_{\boldsymbol{i t}+\boldsymbol{k}}\right)$ on an annual basis for all the properties contacted, using the confidence interval estimator of $\left(\boldsymbol{R}_{\boldsymbol{i t}}-\boldsymbol{R}_{\boldsymbol{i t + k}}\right)$ when variance of $\boldsymbol{R}_{\boldsymbol{i t}}$ and $\boldsymbol{R}_{\boldsymbol{i t + \boldsymbol { k }}}$ are unequal was $62.66 \pm 0.09$ for all the properties combined, 48.14 \pm 0.16 for Single room Apartment, 66.53 \pm 0.35 for Chamber and Hall Apartment, 102.75 \pm 0.89 for Two bedroom Apartment and 41.66 \pm 1.32 for Three bedroom Apartment property types (see table 4). 
Table 4: Extent of differences in non-flooded and flooded rental values

\begin{tabular}{|l|c|}
\hline Property Type & Differences in Non-flooded and Flooded Rental Values \\
\hline Single Room & $48.14 \pm 0.16$ \\
\hline Chamber and Hall & $66.53 \pm 0.35$ \\
\hline 2 Bedroom & $102.75 \pm 0.89$ \\
\hline 3 Bedroom & $41.66 \pm 1.32$ \\
\hline All & $62.66 \pm 0.09$ \\
\hline
\end{tabular}

It was found that discount in rental values is one of the major impacts of flooding on residential properties in Kumasi. Understanding the empirical findings from this study does not only provide information on the dilemmas in the rental market but also and more importantly, calls for an urgent policy action in Ghana in general and Kumasi in particular where relatively high proportions of the dwelling units (38.0\%) are occupied by tenants (GSS, 2010). In line with the previous research by Lamond and Proverb (2006) on the impact of flood on residential property values and on the basis of the evidence presented, the results support the thesis of the negative impact of flooding on residential rental values but rejects the postulations of Montz (1992) and Tobin and Montz (1994) that there is a positive relation between flood and property values.

The study shows that the flood impact on rental values is not uniform across all residential property types as there are variations. The four residential property types contacted had differing sensitivity to floods in the study area. The non-flooded single room, chamber and hall, two bedroom and three bedroom property types exhibited rental values differentials of GHS $48.14 \pm 0.16$, GHS 66.53 \pm 0.35 , GHS $102.75 \pm 0.89$ and GHS 41.66 \pm 1.32 over their flooded equivalents respectively. These results illustrate that every residential property type has different rental value responsiveness to flood impact or event. This supports the assertion by Geltner et al, (2006) and Lamond et al., (2007) that, the swivel of rental value and its dynamics include the demand side elasticity and the supply side elasticity of a particular real estate space type. These findings are also in line with comments by Larsen (2010, 2012), that rental values depend on the demand and supply of a given property type. Again, these findings buttress the views of many real estate writers such as Geltner et al., (2006) that real estate space market, like residential property market in our study are highly segmented along both geographical and property type (sub) markets. Our findings make it difficult to draw definitive or even generalized policy conclusions and therefore call for a broader contextualization of the spatial dynamics in rental values. The study also supports the studies of Selim (2008) and Olujimi\& Bello (2009) who used the hedonic regression model to understand(dis) amenities influencing house rents in Turkey and Nigeria. They observed that impact of flooding on residential properties depended on for example the type of house, type of building, and number of rooms. 


\section{Conclusion and Recommendations}

The study has shown that flood event can serve as a significant disamenity to residential rental values at variant extent depending on the property type. The results present a number of policy implications for the residential housing market. First, potential landlords should be aware where and when to invest in order not to lose lifetime investments to flooding events. To this end, having historical records of the location and a prior knowledge of the geography of the residential location should be paramount. Secondly, real estate developers need to have a good understanding of how flooding events impacts negatively on residential rental values in order to design appropriate management policies for resilient residential housing properties. The findings can, with further elaboration, provide the basis for re-thinking the current urban land use policy where high population growth and high prizes for a parcel of land have affected land right and ownership, a situation that has compelled many residents to settle on 'waste lands' including flood liable areas. The evidence suggests that in order to build a more sustainable city, government needs to enforce the urban planning policy to make sure that people do not build in flood prone areas. Directly relating to explicit rental policy, the government needs to embark on innovative ways of providing affordable housing to the rapidly expanding urban population. These efforts could be closely linked to wider macroeconomics strategies, including those aimed at enhancing the availability of adequate housing finance in order to stimulate private housing investment.

\section{References}

Adegoke, O. J. (2014). Critical factors determining rental value of residential property in Ibadan metropolis, Nigeria. Property Management, Vol. 32, No. 3, pp. 224-240.

\section{Aliyu A. A., Kasim R. B., Martin D., MohdLizam, M. L. M. and Hishamuddin, H. M.} (2012), "Implication of intangible location attributes on residential segregation in Jos, Nigeria. Journal of Sustainable Development, Vol. 5, No. 11, pp. 65-81.

Anas, A. (2006). A model of residential change and neighbourhood tipping. Journal of Urban Economics, Vol. 7, No. 5, pp. 358-370.

Appraisal Institute (2001). The appraisal of real estate, $12^{\text {th }}$ edition: Appraisal Institute, Illinois, USA.

Bailey, M. (2004). Effects of race and other demographic factors on the value of single family homes. Journal of Land Economics, Vol. 2, No. 6, pp. 69-180.

Bello, V.A. (2007). Flooding and property values in the built environment: a case study of AlaRiver in Akure: An International Conference Paper on Towards a 
Sustainable Built and Natural Environment. Faculty of Environmental Design and Management: Obafemi Awolowo University, Ile-Ife.

Bialaszewski, D. and Newsome, B.A. (1990). Adjusting comparable sales for floodplain location: the case of Homeworld Alabama. The Appraisal Journal, Vol. 58 No. 1, pp. $114-8$.

Bruch, E. (2006). Residential mobility, income inequality, and race/ethnic segregation in Los Angeles. Population Association of America (PAA) 2006 Annual Meeting Program, Los Angeles, CA, Availableathttp://paa20o6.princeton.edu/download.aspx. Accessed: 4th October, 2014.

Cauley, S., Pavlov, A. and Schwartz, E. (2007). Homeownership as a constraint on asset Allocation. Journal of Real Estate Finance and Economics, Vol. 34, pp.283-311.,

Cheshire, P. (2007). Segregated neighbourhoods and mixed communities: A critical analysis. London: Joseph Rowntree Foundation and LSE.

Choe, J. and Peterson, L. (2009). Social capital and crime in the United States: paper presented at the 67th Annual Meeting of Midwest Political Science Association, 2 August, Chicago, IL, available at: www.allacademic.com/meta/p361326_index. html. Accessed 3rd January, 2015.

Danquah L, Abass K, Nikoi A.A. (2011). Anthropogenic pollution of inland waters: the c ase of the Aboabo River inKumasi, Ghana. Journal of Sustainable Development. Vol. 4, No 6, pp. 9-21.

Douglas, I. (1998). Urban floodplains and slopes: the human impact on the environment in the built-up area in Gardiner, A., Hindle, P., McKendrick, J. and Perkins, C. (Eds), Exploring

\section{Greater Manchester: A Fieldwork Guide, Manchester Geographical Society, Manchester. Available at: www.mangeogsoc.org.uk/egm/5_1.pdf. Accessed 7th March, 2010.}

Efstratiadis, A., Koussis, A. D., Koutsoyiannis. D. and N. Mamassis1 N. (2013). Flood design recipes vs. reality: can predictions for ungauged basins be trusted? Nat. Hazards Earth Syst. Sci. Discuss., Vol 1, pp. 7387-7416.

Environment Agency, DEFRA (2004). The appraisal of human related intangible impacts of flooding: Joint technical report FD2005/TR, DEFRA/EA R\&D. 
Eves, C. (2004). The impact of flooding on residential property buyer behaviour: an England and Australian comparison of flood affected property. Structural Survey, Vol. 22 No. 2, pp. 84-94.

Fanning S, Grissom T, Pearson T. (1994). Market analysis for valuation appraisals. Appraisal Institute, Chicago.

Galster, G. Cutsinger, J. (2007). Racial settlement and metropolitan land-use patterns: Does sprawl abet Black-White segregation? Urban Geography, Vol. 28, No. 6. pp. 516553.

Geltner, D. M., Miller, N.G., Clayton, J. and Eichholtz, P. (2006). Commercial real estate analysis and investments: (2nd Ed.) Massachusett: LEAP Publishing Services, pp. 3-21.

Gibbons, S. and Machin, S. (2003). Valuing English primary schools: Journal of Urban Economics, Vol. 53, pp. 197-219.

Gibbons, S. and Machin, S. (2005). Valuing rail access using transport innovations: Journal of Urban Economics, Vol. 57, pp. 148-69.

GSS (2010). Final Report on Population and Housing Census, Accra: Sakoa Press Limited, Ghana Statistical Service.

Harrison, D. M., Smersh, G. T. Schartz, J.R. (2001) Environmental determinants of housing prices: The impact of flood zone status. .Journal of Real Estate Research, Vol 21, No. 2, pp. 3-20.

Howley, P. (2009). New residential neighbourhoods within the inner City: An examination of neighbouring. Irish Geography, Vol. 42, No.1, pp. 327-356.

Karley N. K. (2009). Flooding and physical planning in urban areas in West Africa: Situational analysis of Accra, Ghana, TERUM, 4(13).

Karley, N. Kand Akomea S. (2007). An overview of the real estate market in Ghana: Paper presented at the 12th AsRES Annual Conference and 2007 AREUEA International Conference, July 9-12, Macau, China

Kim, C.W., Phips, T.T., Anselin, L. (2003). Measuring the benefits of air quality improvement: A spatial hedonic approach; Journal of Environmental Economics and Management, Vol. 45, pp. 24-39.

Kleinhans, R. (2009). Does social capital affect residents' propensity to move from restructured neighbourhoods? Housing Studies, Vol. 24 No. 5, pp. 629-51. 
KMA, (2014). Kumasi Metropolitan Assembly: Data for purposes of planning waste management intervention programmes. Kumasi, Ghana.

Lamond, J., Proverbs, D. and Antwi, A. (2005).The effect of floods and floodplain designation on the value of property: an analysis of past studies“, Proceedings of the Second Scottish Conference for Postgraduate Researchers of the Built and Natural Environment, Glasgow Caledonian University, November, pp. 633-642.

Lamond, J. and Proverbs, D. (2006).Does the price impact of flooding fade away? Structural Survey, Vol. 24 No. 5, pp. 363-377.

Lamond, J., Proverbs, D. and Antwi, A. (2007). Measuring the impact of flooding on UK house prices: A new framework for small sample problems. Property Management: Vol. 25 No. 4, pp. 344-359.

Larsen, J. E. (2010). The impact of buyer-type on house price; some evidence from the USA: International Journal of Housing, Markets and Analysis, Vol. 3 No. 1, pp. 22-31.

Larsen, J. E. (2012). The impact of a letter of map amendment on floodplain property value. American Journal of Economics and Business Administration, Vol. 4, No. 3, pp.172-179.

Leggett, C.G. and Bockstael, E.B. (2000).Evidence of the Effects of Water Quality on Residential Land Prices: Journal of Environmental Economics and Management, Vol. 39, pp. 121-144.

Lukkarinen, M. (2005).Community development, local economic development and the social economy. Community Development Journal, Vol. 4 o No. 4, pp. 419-24.

Mansfield, C., Pattanayak, S.K., McDow, W., McDonald, R., Halpin, P., (2005). Shades of green: measuring the value of urban forests in the housing market. Journal of Forest Economics 11, 177-199.

Montz, B.E. (1992).The effect of flooding on residential property values in three New Zealand communities. Disasters, Vol. 16 No. 4, pp. 283-98.

Montz, B.E. (1993). The hazard area disclosure in NZ, the impact on residential property values in 2 communities. Applied Geography, Vol. 13 No. 3, pp. 225-42.

Munich Reinsurance Company (2013). Natural Catastrophic Service Database. Munich, Germany: Munich Re Geo Risks Research.

NADMO (2014). Annual Report on Flooding in Kumasi, Republic of Ghana: National Disaster Management Organisation. 
Nilsson, J., Rama, A.K. and Kabir, Z.N. (2006). Social capital and the quality of life in old age. Journal of Aging Health, Vol. 18 No. 3, pp. 419-34.

OCHA (2012).United Nations Office for the Coordination of Humanitarian Affairs, Annual Disaster Report.

Olujimi J. A. B. and Bello, M. O. (2009). Effects of Infrastructural Facilities on the Rental Values of Residential Property. Journal of Social Sciences Vol. 5, No. 4, pp. 332-341.

Omane, O. K. (2002). Peri-urban water quality monitoring in the Sisa-Oda catchment of Kumasi (Unpublished master's thesis). Kwame Nkrumah University of Science and Technology, Kumasi, Ghana.

Oppong, B. (2011) Environmental hazards in Ghanaian cities: The incidence of annual floods along the Aboabo River in the Kumasi Metropolitan Area (K.M.A) in the Ashanti region of Ghana: A Thesis submitted to the Department of Geography and Rural Development, Kwame Nkrumah University of Science and Technology.

Oxford, S (2002). Valuing locational externalities - GIS and multilevel modelling approach. Environment and Planning B, Planning and Design, Vol. 28, No 1, pp. 105-127.

Owusu-Sekyere, E. (2014). Scavenging For wealth or death? Exploring the health risk associated with waste scavenging in Kumasi. Ghana Journal of Geography, Vol. 6, pp. $63-80$.

Owusu-Sekyere, E., Attakora-Amaniampong, E., Aboagye, D. (2016). Wealth, health and inequality: Households exposure to environmental hazards. Geography Journal Volume 2016, Article ID 6231020.

Pryce, Gwilym, Chen, Yu and Galster, George (2011). The impact of floods on house prices: An imperfect information approach with Myopia and Amnesia: Housing Studies, Vol. 26: No 2, pp. 259-279.

Samwinga, V., Proverbs, D. and Homan, J. (2004).Exploring the experience of UK homeowners in flood disasters. Proceedings of the International Construction Research Conference of the Royal Institute of Chartered Surveyors.

Selim, S. (2008). Determinants of house prices In Turkey: a hedonic regression model. Doğuş Üniversitesi Dergisi, Vol. 9 No. 1, pp. 65-76.

Tobin, G.A. and Montz, B.E. (1994).The flood hazard and dynamics of the urban residential land market: Water Resources Bulletin, Vol. 30 No. 4, pp. 673-85. 
UNISDR (2011). Global assessment report on disaster risk reduction - revealing risk, redefining

\section{Development: United Nations, Geneva.}

Wisner, B., Blaikie, P., Cannon, T., and Davis I. (2004). At risk: natural hazards, people's vulnerability and disasters ( $2^{\text {nd }}$ edition). London: Routledge.

Woolley, M.E., Grogan-Kaylor, A., Gilster, M., Karby, R.A., Grant, L.M., Reischl, T.N. and Alaimo, K. (2008). Neighbourhood social capital, poor physical conditions, and school achievement. Children and Schools, Vol. 30 No. 3, pp. 133-45.

Wordsworth, P. and Bithell, D. (2004). Flooding in buildings: Assessment, limitation and rehabilitation. Structural Survey, Vol. 22, No. 2, pp. 105-109

Yankson, P. W. K. (2012). Rental housing and tenancy dynamics with particular focus on

low-income households in Greater Accra Metropolitan Area. In The Mobile city of

Accra, ElizabethArdayfio-Schandorf, Paul w. K. Yankson (eds). CODESRIA

Zhou, B and Kockelman K. M. (2008). Self-selection in home choice: Use of treatment effects in evaluating relationship between built environment and travel behaviour, Transportation Research Record. Journal of the Transportation Research Board, 2077(1), pp. 54-61. 